\title{
半導体レーザの磁界による発振波長シフトの 諸特性〜ビート信号を用いた測定〜
}

\begin{tabular}{|c|c|c|}
\hline 非会員 & 松田真也 & (新渴大) \\
\hline 非会員 & 柴田和則 & (新潟大) \\
\hline 非会員 & 中野博之 & ( 新潟) \\
\hline 正 員 & 佐 藤 & （新潟 \\
\hline 非会員 & 大河正志 & （新渴 \\
\hline 正 員 & 丸山武男 & (新潟 \\
\hline 正 員 & 榛葉 實 & （東京電 \\
\hline
\end{tabular}

Some Oscillation Wavelength Shift Characteristics of a Semiconductor Laser in a Magnetic Field Observation Using a Beat Note

Shinya Matsuda, Kazunori Shibata, Hiroyuki Nakano, Non-members, Takashi Sato, Member, Masashi Ohkawa, Non-member, Takeo Maruyama, Member (Niigata University) Minoru Shimba, Member (Tokyo Denki University)

In papers published previously, we discussed the oscillation wavelength shift of semiconductor lasers in a magnetic field, at room temperature. Observations were carried out by means of a monochromator, which was able to measure the oscillation wavelength shift only in a steady state and subject to a certain degree of measurement errors. In this work, we used the beat note between two semiconductor lasers as a means of observing the wavelength shift. This method reduces overall measurement error down to about one tenth that obtained using the monochromator and enables us to observe the time dependence of the wavelength shift, after setting up a magnetic field. The observed wavelength shift was delayed, compared with the square of the magnetic flux density which is proportional to the wavelength shift in a steady state. This delay measured about $0.07 \mathrm{~s}$, which is much longer than we actually expected, when changing temperature in an active layer.

$$
\text { キーワード：半導体レーザ，発振波長シフト，磁界，時間遅れ，ビート信号 }
$$

\section{1.まえがき}

半導体レーザの発振波長は, 注入電流, レーザ温度, 組 成によって変化するが,これら以外に磁界や压力によって も変化することが知られている。この内, 注入電流, レー ザ温度や組成による発振波長の制御は, 光通信や分光学な どの分野で応用されている。しかし，注入電流やレーザ温 度だけの波長制御では, 半導体レーザの発振波長のもつモ 一ドジャンプ特性のため, 任意の波長を発振させることが 困難である。そこで，これまで主として半導体レ一ザの物 性的研究に用いられてきた，磁界による波長シフトに著者 らは注目し，波長制御への応用の可能性の检討を始めた。 しかも, 従来の磁界による波長シフトの研究は, 極低温,
強磁界における研究で(1)い1)，近年開発されている常温 で連続発振する様々な内部構造をもつ半導体レーザを用い た研究ではなかった。著者らは，これら常温で発振する半 導体レーザを用いて，比較的弱い磁界で実験を行い，磁界 による発振波長シフトの観測に成功し，そのシフト機構の 解明の研究を行ってきた(5) -(9)。

本研究の初期には， R b 原子の吸収線を用いて大きな波 長分解能をもつ観測系を構成して実験を行い，小さな波長 シフトを観測することに成功した(5)。その後は通常のモ ノクロメータを使って，様々な内部構造をもつファブリ・ ペロー共振器形のＧａＡＩＡＳレーザダイオードの波長シ フトの実験を行い，波長シフトを観測してきた。これらの 実験において，波長シフトは磁界の印加方向に依存すると 
いう結果が得られた。また、この波長シフト量は半導体し 一ザの内部構造により異なった (7)。波長以外の特性変化 として注入電流と光出力の関係の测定を行い，この結果よ り，磁界を印加した場合に光出力が滅少することを確認し $た^{(\text {() }}$ 。以上のことから，磁界による波長シフトは半導体 レーザ内部の温度の上昇による影響が大きいのではないか と考えた。しかし，モノクロメータを用いる観測方法では 分解能の関係で品差が大きいことが久点であった。また定 常状態の測定しか行えなかったので，波長シフトの時間芯 答を知ることができず，詳細な検討が行えなかった。そこ で今回は，2つのレーザ光間のビート信号を用いることで 大きな波長分解能をも方, 波長シフトの時間変化も観测で きる方法を考案し実験を行った 実蛤で最も再現性の良いIS (Inner Stripe) 形半導体レ 一ザ(10)を用いた。その結果, 波長シフトの時間变化を初 めて測定すると共に、これまでのモノクロメータを用いた 実験の結果を、誤差を低減させたより精度の高い結果とし て再確認することができた。

極低温，強磁界の条件下の研究で観測されている波長の 短波長側へのシフトの説明は, 磁界により半導体のエネル ギーバンド中に形成されるランダウ準位により行わ机てい る(2)。また, 量子井戸構造の半導体レーザを用いて, 磁 界によりキャリアの自由度を下げ, 量子細線構造の半導体 レーザを実現する研究が報告されているが, これも極低温, 蝶磁界の条件下での研究であり，ランダウ準位が形成され る条件での研究である ‘)。しかし, 著者らの研究の場合, 実験条件および赛験結果より，波長シフトの機構はランダ ウ準位の形成によるものでは説明できないので，仮説を立 てて説明を試みてきた(7)、(夕)。これまでの報告である程 度までの説明がなさ机てきたが，著者らはまだ十分説明で きたとは考えていない。ここでは，時間变化を調べるなよ゙， 今回の新たな実験方法により得られたいくつかの実験結果 を用いて、これまで考えてきた波長シつトのメカニズムに 更に考察を加え，常温で比較的弱磁界における半導体レー ザの特性の变化を検討したので報告する。

\section{2. 実検方法之実殹結果}

図1に実験系を示す。実験に用いた半導体レーザはIS 形半導体レーザで，発振波長は780〜790n mである。 実験にIS形半導体レーザを用いたのは，これまでの実験 で最も再現性がよく波長のシフト量も比較的大きかったた めである。半導体レーザの磁性体でできている保護キャッ プを取り外し，その上で $7 \mathrm{~mm} \times 7 \mathrm{~mm} \times 7 \mathrm{~mm}$ 電磁石 の磁極間に半導体レーザを固定する。この半導体レーザを LD 1 とする。このL D 1のレーザに磁界を印加して生じ る波長シフト量を测定する。次に，测定する場合に波長の 基準となる半導体レーザを用意する。これをL D 2 とし L D 1 とほぼ等しい波長で発振させる。ビート信号を観测す るため、この光学系では L D 1 と L D 2 の光路をビームス
プリッタ（BＳ）やミラーを用いて一致させてアバランシ エホトダイオード（APD）に導いている。その出力をス ペクトラムアナライザに入力して，2つのレーザLD 1 と L D 2 の発振周波数 $\mathrm{f}_{1}$ と $\mathrm{f}_{2}$ の差周波数 $\Delta \mathrm{f}=1 \mathrm{f}_{1}$ $\mathrm{f}_{2} \mid$ をビート信号として検出した。なお，本実験ではレ 一ザの動作条件を一定にする必要があるため，温度制御回 路を用いてLD 1，LD 2 れぞれ温度の変動を長期的に は1 $/ 100{ }^{\circ} \mathrm{C}$ 以下（周波数变動では $300 \mathrm{M} \mathrm{z}$ 以下） に制御してある。個々の実験に要する時間（約 5 秒）程度 の短期の温度安定度は，磁界の影響を受けないLD 2 にお いては実験の再現性から約 $1 / 1000{ }^{\circ} \mathrm{C}$ 程度とさらに高 いものと思われる。

これまでモノクロメータを用いた実験では $500 \mathrm{MHz}$ （波長に直すと約 $0.001 \mathrm{~nm}$ ）以下のシフト量は測定 できなかったが，今回のビート信号を用いた実験方法によ り約 $50 \mathrm{MHz}$ 程度のシフト量を観測できるようになった。 これまでは，磁束密度 $1.4 \mathrm{~T}$ を印加した場合についての みの実験であったが，少ないシフト量も測定できるように なったため，様々な強さの磁束密度で実験した。

これまでの研究より波長シフトは磁界の印加方向に依存 することが確認されているため, 磁界の四加方向とレーザ の角度並びにそのなす角 $\theta$ の定義について図 2 , 図3に示 す。半導体レーザの結晶の積層面に对する法線方向べクト ルを $\mathrm{n} と し$, 磁束密度べクトルを $\mathrm{B}$ とする。このnと $\mathrm{B} か ゙$ 平行 $(\mathrm{B} / / \mathrm{n})$ になる場合と垂直 $(\mathrm{B} \perp \mathrm{n})$ になる場合に ついて磁界を印加し波長のシフト量を測定した。をの結果 を図4に示した。スペクトラムアナライザは䋓対值で表示 されるので，0 M H 2 の位置で波形が折り返される。そこ でここに示した波形では大きなシフト量を観測することを

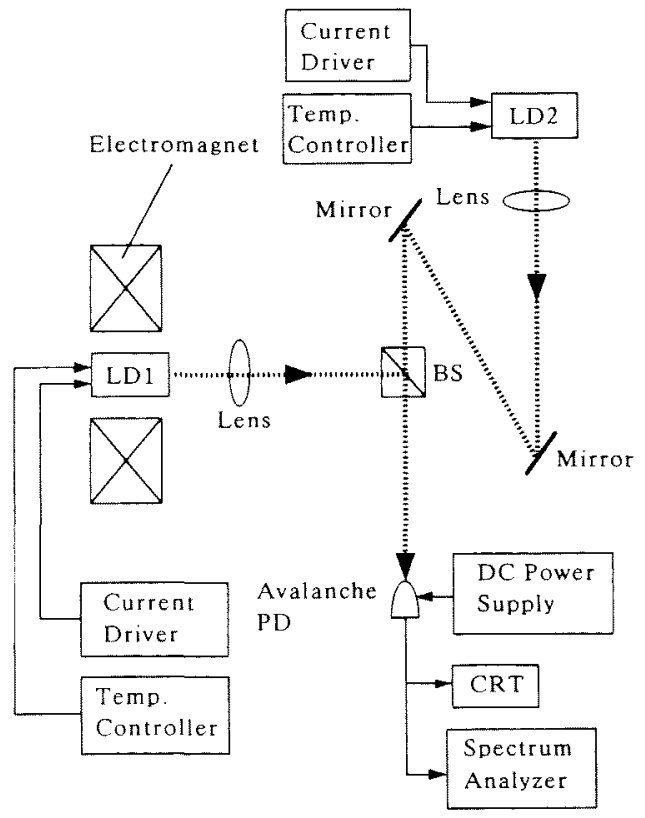

図 1 実験系

Fig. 1. Experimental setup. 
可能にするためにあらかじめ基準となるゼロ磁界での図 4 （a）の波形は中心から移動させてある。ここでは, 平行 に磁束密度 0.65 T 印加した図 4 (b) と1. 12 T を印加した図4（c）を示した。図4（c）の波形は折り 返されているのでシフト量が約 $1.0 \mathrm{GH} \mathrm{z}$ あったことが 確認できる。波長シフトの方向はモノクロメータを用いた 実験結果より長波長側であることがわかっている。図には 示してないが磁束密度 0.93 T印加した場合は約 400 $\mathrm{MH} \mathrm{z}$ のシフトが観測された。これらの結果から周波数シ フトの磁界依存性を調べると図5のようにシフト量が磁束 密度の 2 乗に比例することが確認できた。

本実験においては磁界の印加方向とレーザの角度も重要 となる。そこで, 直線偏光板を用いて, 半導体レーザ光が レーザの結晶の積層面に平行な偏光をむつ直線偏光（䈌密 には，わずかにだ円偏光）である性質を利用して測定する ことで, 磁界の方向を正確に測定する方法を考案した。こ の角度依存性についての実験結果を図6に示す。図より, 磁界の印加方向が $\theta=0^{\circ} \quad(\mathrm{B} / / \mathrm{n})$ の場合に, 約 700 $\mathrm{MH} \mathrm{z}$ の周波数シフト量が観測され， $\theta=90^{\circ} \quad(\mathrm{B} \perp \mathbf{n})$ の場合はシフトは観測されず，角度を平行から垂直に変え ていくとシフト量が滅少しているのがわかる。なおこの 実験ではスペクトラムアナライザで正確に測定できるよう に比較的大きなシフト量になる磁束密度 $0.93 \mathrm{~T}$ を印加 した。

モノタロメータを用いた同様の実験でも, 波長のシフト

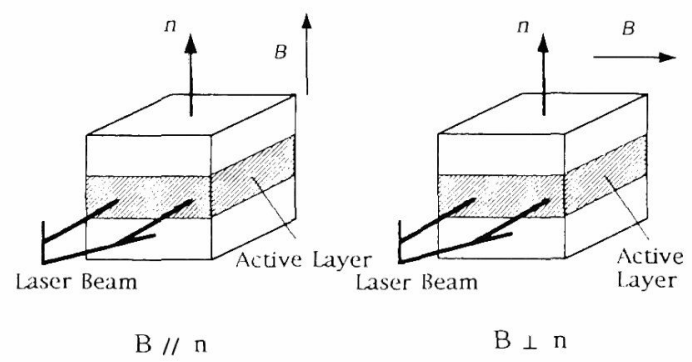

図 2 磁界の方向の定義

Fig. 2. Definition of a magnetic field

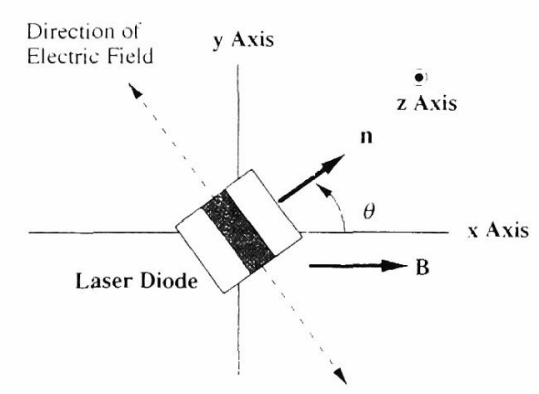

図 3 磁束密度ベクトル B と法線ベクトル $\mathrm{n}$ のなす角度 $\theta$

Fig. 3. Angle $\theta$ between magnetic flux density $B$ and normal vector $n$.

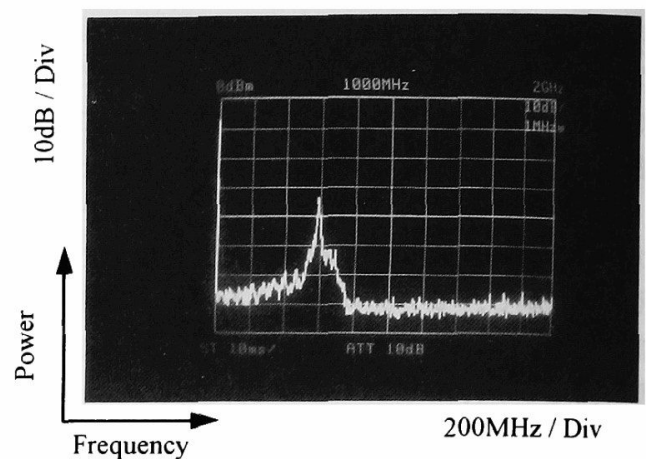

(a) $\mathrm{B}=0 \mathrm{~T}$

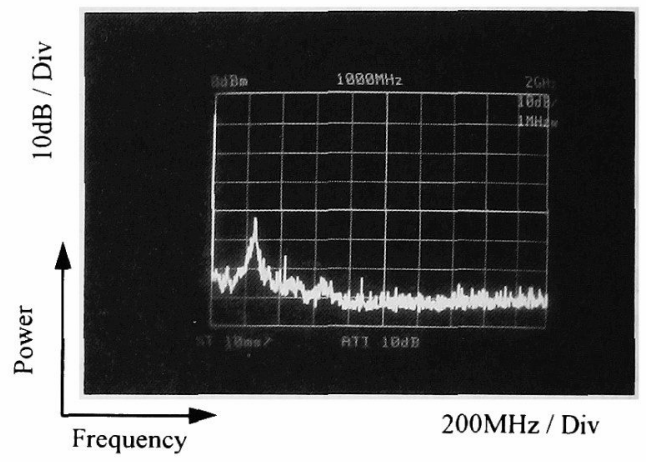

(b) $\mathrm{B}=0.65 \mathrm{~T}$

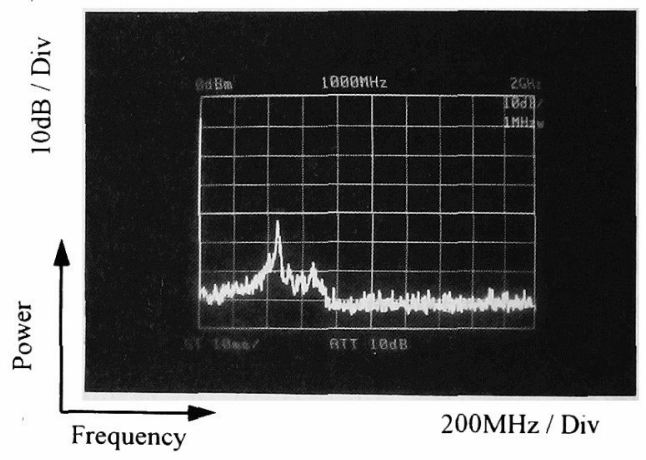

(c) $\mathrm{B}=1.12 \mathrm{~T}$

図 4 ビート信号波形

Fig. 4. Beat note spectrum.

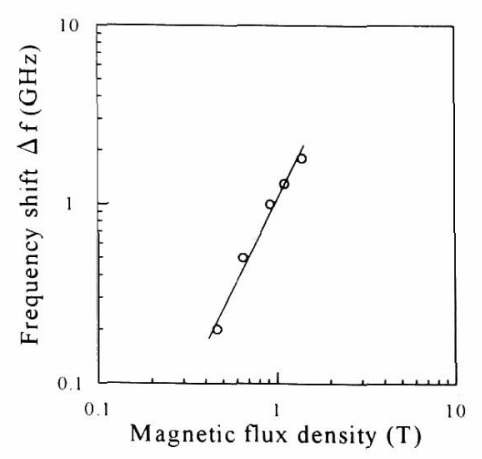

図 5 周波数シフトの磁界依存性

Fig. 5. Dependence of frequency shift on magnetic flux density $B$. 
量が cos ${ }^{2} \theta$ の関数に従うという結果を得ていたが，読 取り誤差が大きいためにエラーバーがさ250 M H z と大 きいものだった。今回も，過去の実験結果と後述する理由 から波長のシフト量が $\mathrm{c} \mathrm{Os}^{2} \theta$ の関数に従うと考えてフ イッティングすると今回の実験のエラーバーであるさ 25 $\mathrm{MH} \mathrm{Z}$ に収まる結果となり，ビート信号を用いた実験方法 においても波長シフトの角度依存性が c o s ${ }^{2} \theta$ の関数に 従うことがわかった。

これまでの実験方法では定常状態の観測しか行えなかっ た。しかし，著者らが考えているレーザ内部の温度変化が 波長シフトの原因とする理論の詳細な検討のためには波長 シフトの時間変化を測定することが重要である。今回，ビ ート信号を用いることでこの問題点を解決することができ た。最初にスペクトラムアナライザの検出信号を磁界を印 加する前から除去するまでの間ビデオカメラで撮影する。 ここで用いたビデオカメの 1 コマは， $1 / 30 \mathrm{~s}$ （=約 $0.033 \mathrm{~s})$ である。撮影した周波数シフト量 $\Delta \mathrm{f}$ とそ の時のテープのコマ数を評価することによって時間変化を 観测する。磁界の大きさの時間変化と発振波長の時間变化 との関係を調べるために, 次にオシロスコープで電磁石電 流 $\mathrm{i}$ の変化を測定し，ビテオカメラで撮影した。そして， そのコマ数とその時の電流值を評価することで電流值の時 間变化を測定した。この実験で使用している電磁石は鉄心 を使用しているため，電磁石電流と発生する磁界の間に時 間遅れがあると考えられる。そこで，G a A s ホール素子 を用いて電流に対する発生磁界の時間变化を調へた。ここ で用いたホール素子は出力電开において磁界の变化に対す る時間遅れがないことを確認しており，出力電王の温度保 数が小さく，直線性が良いので磁界の大きさを単純に示し ているということができる。

図 7 に碳束密度 $0.63 \mathrm{~T}$ と $0.93 \mathrm{~T}$ を印加した場合 のビート信号による周波数シフト量 $\Delta \mathrm{f}$ の測定結果亡電磁 石電流 $\mathrm{i}$ ，ホール素子の出力電圧から算出された印加磁束 密度 $\mathrm{B}$ とその 2 乗である $\mathrm{B}^{2}$ の時間变化を示す。縦軸のス ケールは，周波数シフト量 $\Delta \mathrm{f}$ はその大きさを $\mathrm{MHz}$ z で， 電磁石電流 $\mathrm{i}$, 印加磁束密度 $\mathrm{B}$ とその 2 乗の $\mathrm{B}^{2}$ はそ扎ぞ

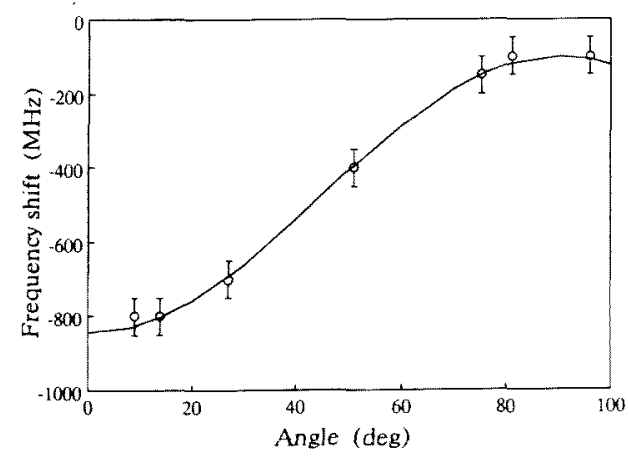

図6 周波数シフトの角度依存性

Fig. 6. Dependence of frequency shift on angle $\theta$.
れの最大值を 1 として $\Delta \mathrm{f}$ 最大值に合わせ込んだものを 示してある。罒5に示したように $\Delta \mathrm{f}^{2} \mathrm{~B}^{2}$ に比例するこ とがわかっている。そこで, $\mathrm{B}^{2}$ と $\mathrm{f}$ の時間变化の様子 を比較すると、磁界を印加した直後は $\mathrm{B}^{2}$ の变化に対して $\Delta \mathrm{f}$ の変化が図7に示すどちらの場合においても荤れてい ることがわかる。遅れが最大になるところでは $0.07 〜$ 0. $1 \mathrm{~s}$ ほど遅れがあった。この実験は幾つかの試料を用 いて行った。定量的には若干のばらつきはあったが, どの 試料でも磁界印加直後から B $^{2}$ に対して時間の遅れが観測 された。図8には磁束密度0.65 Tと0.93 Tを除去 した場合の結果を示す。磁界の除去後についても印加時と 同様にB2 に対して $\mathrm{f}$ が遅れていることが確認された。

また，磁界を印加した場合のしきい值電流 $1 \mathrm{th}$, 光出力 の変化を調べるため, 使用した半導体レーザの電流一光出 力特性を測定した。この測定の時には，図1の実駼系のL D 1 の集光させたレーザ光を光パワーメータに直接入射さ せた。 $\mathrm{B} / / \mathrm{n} ， \mathrm{~B} \perp \mathrm{n}$ の場合の測定結果をそれぞれ図 9

（a），（b）に示す。印加した磁束密度は1．4 Tであ る。この図からかかるように，B//nの場合には磁界を印 加するとわずかではあるが，しきい值電流付近から光出力 が低下している。この時しきい檤電流Ｉnには大電流側に 0. $13 \mathrm{~m} \mathrm{~A}$ 程度のシフトが観測された。また実際に波長 シフトを観測している動作電流付近では $34 \mu \mathrm{W}$ の光出力 の低下が観測された。 $\mathrm{B} \perp \mathbf{n}$ の場合には磁界を印加しても 光出力, しきい值電流の変化は観測されなかった。また，

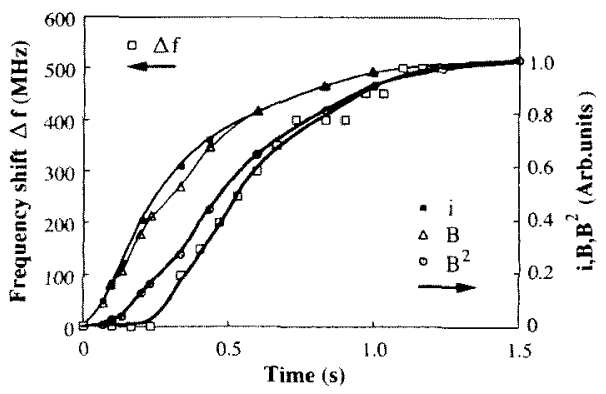

(a) $\mathrm{B}=0.65 \mathrm{~T}$

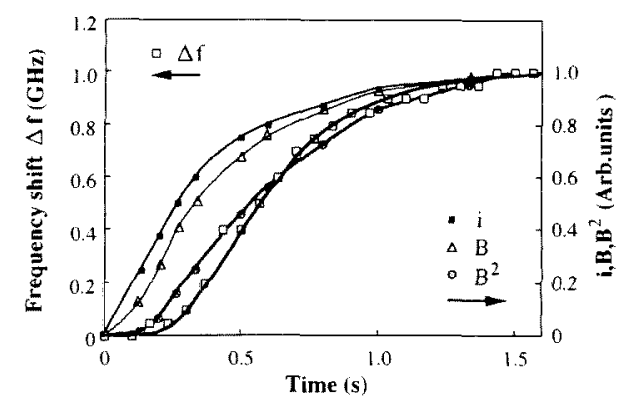

(b) $\mathrm{B}=0.93 \mathrm{~T}$

図 7 磁界印加時の時間变化

Fig. 7. Temporal changes after setting up a magnetic field. 


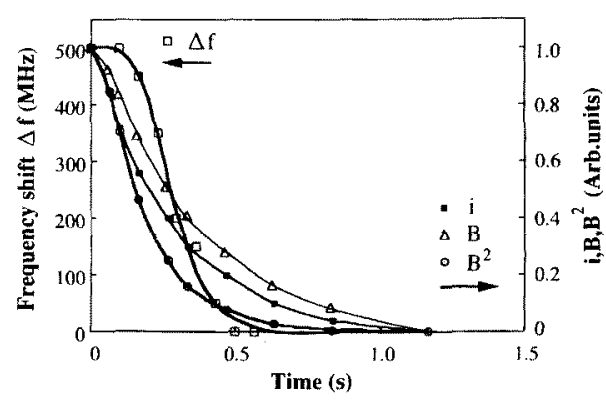

(a) $\mathrm{B}=0.65 \mathrm{~T}$

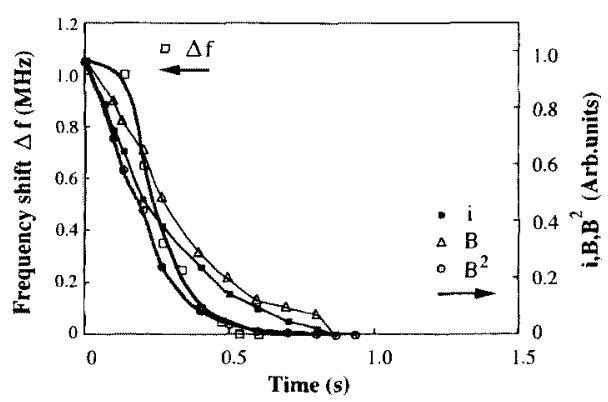

(b) $B=0.93 \mathrm{~T}$

図 8 磁界除去時の時間変化

Fig. 8. Temporal changes after removing a magnetic field.

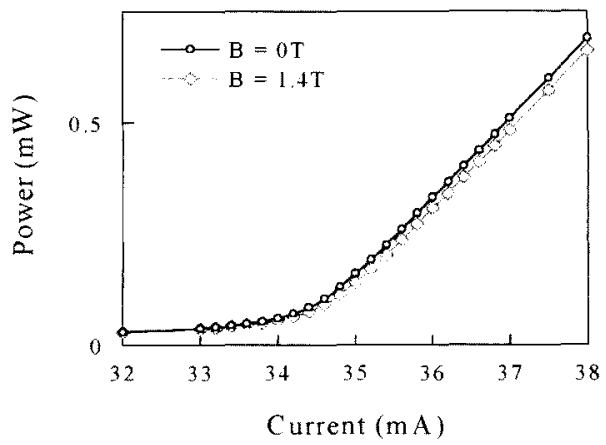

(a) $\mathrm{B} / / \mathbf{n}$

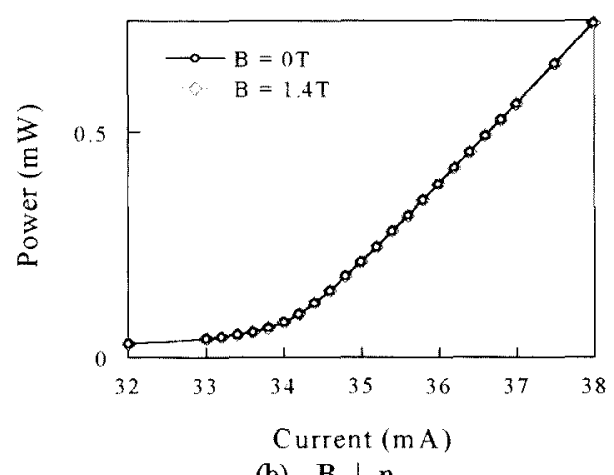

(b) $\mathrm{B} \perp \mathrm{n}$

园9 電流一光出力特性

Fig. 9. Current vs, light power characteristics.

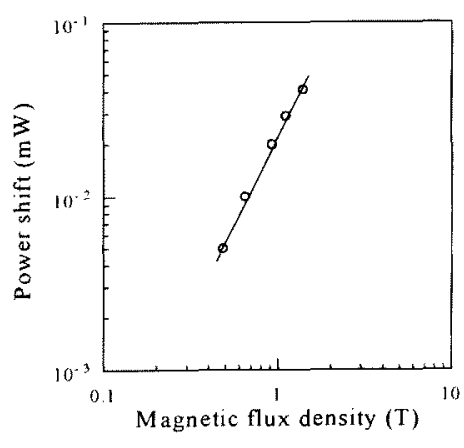

図10 光出力の磁界依存性

Fig. 10. Dependence of light output on magnetic flux density $B$.

光出力シフトの磁界依存性を測定した結果を図 10 に示す。 図から光出力のシフト量においても, 印加磁束密度の 2 乗 $\mathrm{B}^{2}$ に比例することが確認できた。

\section{3. 考察と検討}

極低温，強磁界の下での研究で観測されている短波長側 へのシフトは, 磁界により半導体のエネルギーバンド中に 形成されるランダウ準位により説明されている(2)。しか し，本研究における常温で比較的弱い磁界ではランダウ準 位は形成されない。またここれまでの実験より磁界による 波長シフトは長波長側という結果を得ており、これはラン ダウ準位形成による波長シフトとシフトの方が異なる。 これらのことから，本実験で観測された波長シフトのメカ ニズムはランダウ準位の形成によるものではないと考えら れる。またこの波長のシフトは半導体レーザの内部構造に 强く依存する。そこで著者らは以下のような仮説を立てた。 まず，半導体中を流れる電流（電流の主たる方向はnの方 向）にほぼ平行に磁界が印加されると，電流の拡散が押さ えられて電流密度が高くなると同時に半導体レーザ中を流 れる電流の通路に変化が生じる。その結果, 活性首付近の 温度が上昇し, 共振器長, 屈折率分布, キャリア分布なと が变化し，波長が長波長側へシフトするというものである。

波長シフトの角度依存性が c o s 20 日依存する傾向が 示されたのは，波長シフトの原因が活性層付近の温度変化 の効果であると考えると法線 (電流) 方向と磁界となす角 $\theta$ の変化による磁界の電流への影響は B cos $\theta$ の関数に 従う。図 5 の結果より, 波長シフトは $\mathrm{B}^{2}$ に比例している ことから.この角度 $\theta$ の变化による影晦は $\mathrm{B}^{2} \mathrm{cos}^{2} \theta$ の関数に比例するのだと考えられる。ここで波長シフトが 磁界の大きさの 2 乗に比例する图 5 の結果は, 磁界の大き さに比例した力が半導体レーザに流れる電流に働き，その 電流の 2 乗に電力は比例すること，そして電力に比例して 温度は変化するこよ。つまり，温度の变化は磁界により影 䅉を受ける半導体レーザの電流の变化の大きさの 2 乗に比 例し，その温度の変化に比例して波長がシフトすることに 
よると考えられる。

また， $B^{2} と \Delta f の$ 時間変化の結果より，過渡状態にお いて $\Delta \mathrm{f}$ の遅れが一様ではなく， $\mathrm{B}^{2}$ の変化の割合が大き い所ほど発振周波数のシフトが漣れていることがわかる。 この遅れは大きな可で $0.07 〜 0 ． 10 \mathrm{~s}$ 程度であり， ビテオカメラによる撮影の $2 \sim 3$ コマの荤れに相当する。 温度による効果を考えた場合, 活性層内の発振周波数の温 度応答速度は $\mu \mathrm{s}$ 以下であり, 活性層外からの温度の応答 は余分に時間が掛かることから、この非常に荤い発振周波 数シフトの原因は活性首外の半導体レーザの素子全体にお ける温度変化によるのではないかと考えている。更に図 9

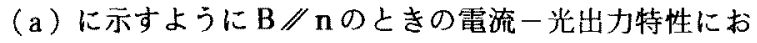
いて，しきい值電流値 $I_{\mathrm{t}}$ が大電流側に変化した実験結果 も，温度が上昇した場合の変化と同じである。一力，動作 点に近い光出力 $2 \mathrm{~mW}$ をえる電流值の磁界による増加が, しきい值電流值の增加よりも大きくなっていることから， 電流が多く流れているときにこの変化が大きくなっている ことがわかる。ここで，B/ nのときには磁界により電流 の拉散が押えられるはずであり電流の閉じ込めが良くなる はずである。通常, 電流の閉じ込めが良くなるということ は，しきい値電流の減少につながることから，余分な発熱 が咸少すると考えられる。従って，磁界に上る電流閉じ这 めに起因する波長シフトは短波舆側に生じるはずである。 しかし，これまでの実験結果から波長のシフト沬長波長側 がほとんどである。そこで著者らは, 磁界の盯加は活性層 内で電流密度の增加を生じ波長を短波長側へシフトさせる のと同時に，活性層外での発熱による活性層の温度上算に 寄与するのではないかと考えた訳である。すなわち， B / nに磁界を印加した場合には磁界による電流の变化のうち， 活性層の温度を上昇させる効果のほうが活性層内の電流密 度の增加をもたらす効果よりも大きいため，長波長側へシ フトしたと考えている。

著者らの立てた仮説が正しいとすると半導体レーザによ りこの波長シフトの大きさが異なることは, 半導体レーザ の内部構造により電流の搪散の特性が異なっていることを 示す。波長シフトが小さいレーザは内部構造により電流の 閉じ込めが十分行われていると考えられ，波長シフトが大 きいレーザは閉じ込めが不十分であるといえる。具体的な レーザの構造で考えると，活性層の所での電流閉じ込めは I S形やV S I S形 (V-Grooved Substrate Inner Stripe) (11)はレーザ内部に構造を持つため良いと思われるが，電 極がストライプ状になっておらず，素子全体としての閉じ 込めに問題がある。そのため I S 形とVS I S 形で大きな シフトが観测されるのだと考えている(8)。一方，CS P 形 (Channelled Substrate planar) い1では, 活性層での 電流の閉じ込めは他のレーザと比較して必ずしも良いとは いえないが，Zn拡散により電流の通路を形成しており，

電極がストライプ状になっていることに相当するため，全 体としては電流の通路がより強く制限され, 波長シフトが わずかであったのだと思われる(8)。

\section{4.む寸び}

これまでの研究から，半導体レーザの磁界による発振波 長シフトはレーザに印加する磁界の方向に偖存し，また半 導体レーザの内部構造によっても異なることがわかってい る。しかしながらこれまでの結果はすべて定常状態の測定 によるものであった。そこで今回は，ビート信号を用いる ことにより周波数シフトの時間変化の測定を行った。測定 には，内部構造が左右対称でこれまで害験に用いた中で波 長シフトが比較的大きく再現性のよいIS 形半導体レーザ を用いた。また，磁界を印加した場合の光出力一電流特性 を測定した。その結果， $\mathrm{B} / / \mathrm{n}$ に磁界を印加した場合にし きい值電流が大電流側にシフトし, 光出力が低出力側にシ フトした。

実験方法にビ一ト信号を用いたことで，測定誤差がモ， クロメータを用いた実験方法に比べて $1 / 10$ 程度に小さ くなったため, 周波数シフトの磁界依存性と角度依存性に ついても精度の高い測定を行えた。そして，周波数シフト が磁束密度の 2 乗に比例することと $\mathrm{cos}^{2} \theta$ の関数に従 う角度依存性を持つことをより高い精度で確想できた。

また，ビート信号を用いる実験方法をとることで周波数 シフトの時間変化を測定することができ, 定常状態では比 例する $\mathrm{B}^{2}$ に比べて $\Delta \mathrm{f}$ が $0.07 \sim 0.1 \mathrm{~s}$ 遅れてシフ トしていることが確認できた。このような遅い周波数シフ 卜は極低温，強磁界での波長シフトの説明に用いられてい るランダウ準位の形成によるものではないことがこれまで の考察で確認されている。これらの結果には著者らの仮説 を支持する内容が多く含まれている。しかしながら考察で も述べたように活性首内での電流密度の增加により波長が 短波長側にシフトする効果もあると考えられるが，見在の 我々の実験装置ではこの効果を確認するのは不可能である。 促って更に応答速度の速い測定方法を考案する必要がある。 また，著者らの結論である「波長のシフトは半導体レーザ の内部構造に依存する」ということを確認するためにも， これまでのG a A l A s を用いた780 $\mathrm{nm}$ 付近の半導体 レーザではなく A l G a I n Pを用いた材料の違う680 $\mathrm{n} \mathrm{m}$ 付近の短波長の半導体レーザを用いた実験を行い，理 論を確立していく必要がある。

既に報告しているT J S 形半導体レーザや，T S 形半導 体レーザのような内部構造が非対称なレーザでは，波長シ フト特性が不安定で個々の試料レーザによりシフト特性が 異なることがある(8)。また，これまで用いた半導体レ一 ザは量子井戸構造のものではないので, 今後これらのレー ザについても更に詳しく検討していく予定である。

本研究を進めるにあたり，実験に協力していただいた平 田光一君に感謝いたします。

(平成 8 年 6 月 24 日受付)

\section{文 献}


(1)I. Melngailis \& R. Rediker : "Magnetically tunable cw InAs diode maser", Appl. Phys. Lett., 2, 11, $202 \sim 204$ (1963-06)

(2)F. Galeener, I. Melngailis, G. Wright \& H. Rediker: "Magnetic Properties of InAs Diode Electroluminescence”, J. Appl. Phys., 36, 5, 1574 1579 (1965-05)

( 3 ) A. Calawa, J. Dimmock, C. Harman \& I. Melngailis:

"Magnetic field dependence of laser emission in $\mathrm{Pb}_{1-x} \mathrm{Sn}_{\mathrm{x}}$ Se diodes”, Phys. Rev. Lett., 23, 1, 7〜 10 (1969-07)

(4) Y. Arakawa, H. Sakaki, M. Nishioka, H. Okamoto \& N. Miura: "Spontaneous emission characteristics of quantum well lasers in strong magnetic fields an approach to quantum-wel1-box light source", Jpn. J. App1. Phys., 22, 12, L804 L806 (1983-12)

( 5 )T. Sato, S. Yashima \& M. Shimba: "Frequency shift of a GaAlAs diode laser in a magnetic field " Electron. Lett., 22, 19, 979 981 (1986-09)

(6)T.Sato, S. Sato \& M. Shimba: "Frequency shift characteristics of a GaAlAs diode laser in a magnetic field”, QELS “89, WDD38 (1989)

（7）佐藤 孝・川島英俊・中村利男・大河正志・丸山武男 ・榛葉 實：「磁界によるG a A 1 A s レーザダイオ ードの発振波長シフト」信学論, J75-C-I，9，579〜 586 (平4-9)

(8)佐藤 孝・川島英俊・星 倫哉・山本茂樹・大河正志 ・丸山武男・榛葉 實：「半導体レーザの磁界による 発振波長シフトとそのシフト機構の検討」電学論, 114, 10, 1031 1038 (平6-10)

(9)T. Sato, S. Matsuda, K. Shibata, S. Yamamoto, M. Ohkawa, T. Maruyama \& M. Shimba: "Oscillation wavelength shift characteristics of a semiconductor laser in a magnetic field", Semiconductor Lasers - Advanced Devices and Applications, TuE13-1 (1995)

（10）末松安晴・伊賀健一：「光ファイバ通信入門」91〜94, オーム社 (1991)

(11)B. Mroziewicz, M. Bugajski \& W. Nakwaski: " Physics of semiconductor lasers”, 228 252, North-Holland, Amsterdam (1991)

松田 真也 (非会員) 1996年新渴大学大学院工学研

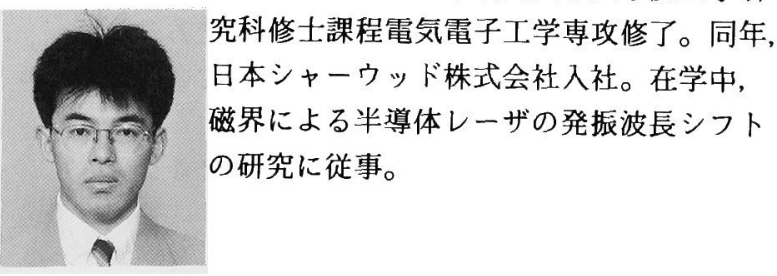

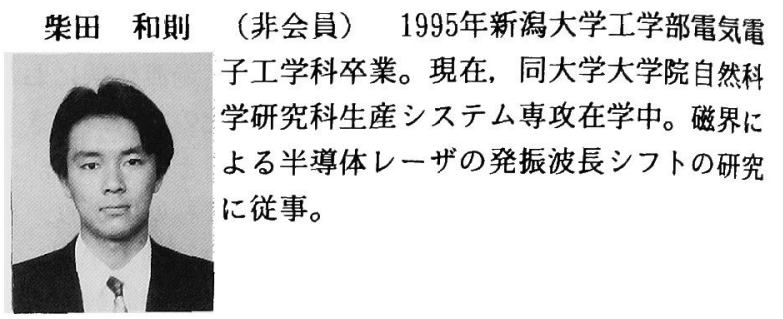

中野 博之（非会員）1994年新潟大学大学院工学研

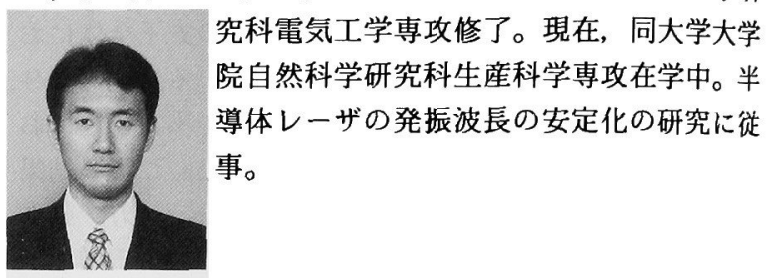

佐 藤 孝 (正員) 1983年京都大学大学院工学研究

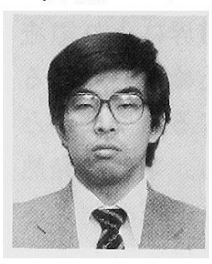
科博士課程電子工学専攻修了。新潟大学工 学部助手を経て, 1995年同教授, 見在に至 る。レーザによる粒子生成, 半導体レーザ の波長安定化の研究に従事。電子情報通信 学会, 日本物理学会, 応用物理学会, レ一 ザー学会，I E E E，OS A 各会員。工博。

大河 正志 (非会員) 1989年大阪大学大学院基礎工

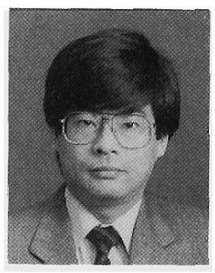
学研究科物理系専攻電気工学分野博士課程 修了。光集積回路, 光計測の研究に従事。 同年, 新潟大学工学部助手。光情報処理の 研究に従事。1995年同助教授, 現在に至る。 電子情報通信学会, 応用物理学会, レーザ 一学会各会員。工博。

丸山 武男 （正員）1965年新潟大学工学部電気工学 科卒業。同年, 新潟大学工学部助手。1989 年新潟大学工学部教授、現在に至る。プラ ズマ物理, 放電現象の基礎, 固体物性の研 究に従事。電子情報通信学会, 日本物理学 会各会員。工博。

莉葉 （正員） 1955年早稲田大学理工学部電気

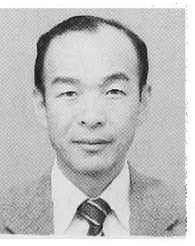
通信学科卒業。同年電電公社電気通信研究 所入所。1983年新潟大学工学部教授。1992 年東京電機大学工学部教授。ミリ波導波管 伝送，準ミリ波アンテナ・伝搬および光伝 送の研究に従事。電子情報通信学会, I E E E 各会員。工博。 